\title{
Strategi Pengemasan Wisata Heritage di Desa Wisata Kerta, Kecamatan Payangan, Kabupaten Gianyar, Bali
}

Dinov Sambadi Adistria Laksana a,1 I Nyoman Sukma Arida a,2

1dinov.sambadi96@gmail.com²sukma.arida@unud.ac.id

a Program Studi Sarjana Destinasi Pariwisata, Fakultas Pariwisata, Universitas Udayana, Jl. Dr. R. Goris, Denpasar, Bali 80232 Indonesia

\section{Abstract}

Tourism is the largest and fastest growing industry in the world. Tourism in one of the most important sector and has a significant influences in the economic development of the country. Tourism contribution is considered important for economic growth in Indonesia, because in addition to bring in foreign exchange, also felt able to open a new job for the community. Tourim in Bali has developed quite rapidly, tourism potentials in Bali has been developed well enough, so that it can be enjoyed by tourists, which became a leading tourist attraction in Bali that is nature tourism and cultural tourism. This research focuses on the planning and strategy of the packaging of heritage tourism products in Kerta Tourism Village in order to improve the local economy, considering that Kerta Tourism Village has so many heritage tourism potential that has not been developed yet. This research is expected to benefit local communities and Gianyar Government in adding data, as preliminary data, and consideration data for further in-depth research. This research has a scope that is limited to two variables, that is identifying the heritage tourism potential owned by Kerta Tourism Village and compile a strategy to package heritage tiourism in Kerta Tourism Village. The data sources used are primary data obtained from interviews with the informants, observations, and documentation in Kerta Tourim Village, and the secondary data is obtained from various books used as the theoretical basis to supporting the research. Based on the results obtained, in Kerta Tourism Village there are many tourism potentials that can be developed into a tourism attraction, one of which is heritage tourism that can be combined with cycling tourism activities and certainly useful for local people and tourists.

\section{Keywords: Heritage Tourism, Cycling Tourism, Kerta Tourism Village.}

\section{PENDAHULUAN}

Pariwisata di Bali sudah berkembang cukup pesat. Potensi-potensi wisata di Bali telah dikembangkan dengan cukup baik sehingga bisa dinikmati oleh wisatawan, wisata alam dan wisata budaya menjadi daya tarik unggulan di Pulau Bali. Kabupaten Gianyar menjadi salah satu wilayah yang sedang gencar mengembangkan potensi pariwisata yang dimilikinya.

Kabupaten Gianyar tidak hanya terkenal dengan beragam kreasi keseniannya, tetapi tedapat juga situs cagar budaya dan arkeologinya, salah satunya adalah dengan banyak ditemukannya Sarkofagus di daerah peninggalan bersejarah pada zaman Megalithikum. Sarkofagus ini memiliki fungsi sebagai kubur batu pada zaman tersebut dan hingga saat ini situs arkeologi Sarkofagus sudah banyak ditemukan dan tersebar di Bali. Beberapa peninggalan bersejarah ditemukan tersembunyi di salah satu desa yang berada di kawasan Kabupaten Gianyar, yaitu Desa Kerta

Desa Kerta di Kecamatan Payangan, Kabupaten Gianyar sedang gencar melakukan pengembangan potensi pariwisata yang dimilikinya. Desa Wisata Kerta yang unggul dengan agrotourismnya ternyata memiliki banyak potensi pariwisata selain pada pertanian dan perkebunannya. Di Desa Wisata Kerta terdapat potensi wisata heritage dimana Heritage tourism menjadi wisata yang semakin populer dan semakin banyak diminati oleh wisatawan lokal maupun mancanegara.

Dari sisi pariwisata, dapat dilihat bahwa sistem pengelolaan kegiatan pariwisata di Desa Wisata Kerta masih perlu ditingkatkan lagi. Selain itu, pengemasan aktivitas-aktivitas kreatif warga dan aktivitas pariwisata sebagai sebuah produk wisata heritage juga belum ada. Berbagai permasalahan tersebut dapat dilihat dari berbagai indikator. Misalnya, ketika ada pengunjung yang datang belum ada alur kunjungan yang sistematis dan efisien sehingga pengunjung pun hanya mendatangi tempat-tempat wisata secara acak dan tidak terarah.

Untuk menemukan arahan pengembangan produk pariwisata secara tepat dan sesuai dengan karakteristik kawasan, penelitian ini fokus mengkaji tentang perencanaan dan strategi pengemasan produk wisata heritage di Desa Wisata Kerta dalam rangka untuk meningkatkan perekonomian masyarakat lokal, mengingat Desa Wisata 
Kerta memiliki begitu banyak potensi heritage yang belum dikembangkan.

Berdasarkan latar belakang tersebut ditemukan permasalahan yaitu bagaimana strategi pengemasan wisata heritage di Desa Wisata Kerta, dan tujuan dari penelitian ini adalah untuk mengidentifikasi potensi wisata heritage serta merancang dan mengemas produk wisata heritage di Desa Wisata Kerta.

\section{TINJAUAN PUSTAKA}

Telaah penelitian sebelumnya sangat penting yang berguna mendapatkan perbandingan antara penelitian saat ini dengan penelitian sebelumnya yang telah dilakukan oleh peneliti lain. Penelitian terdahulu yang relevan adalah penelitian yang dilakukan oleh Fahrul, dkk (2016) dengan judul penelitian "Srategi Pengemasan Wisata Trekking di Daya Tarik Wisata Pura Mangening dan Situs Gunung Kawi, Tampaksiring, Gianyar". Penelitian tersebut memiliki kesamaan fokus dengan penelitian ini, yaitu membahas mengenai pengemasan wisata. Adapun perbedaannya dalam penelitian ini, yaitu penelitian tersebut lebih menekankan pada pengemasan paket wisata heritage dengan mengandalkan potensi fisik pada sisi budaya dan perbedaan lokasi penelitian.

Konsep yang digunakan dalam penelitian ini adalah sebagai berikut. Konsep strategi pengemasan oleh Basri (2005) yang mendefinisikan bahwa strategi adalah pilihan tentang bagaimana cara terbaik untuk mencapai misi organisasi. Konsep wisata heritage oleh Drummond (2001) yang mendefinisikan bahwa heritage adalah apa yang atau mungkin diwariskan, dapat mencakup tradisi, nilai, event historis, mesin industri dari masa lalu, rumah historis, koleksi seni, kegiatan kultural, kekayaan alam seperti pantai, pegunungan, flora, dan fauna. Konsep paket wisata oleh Darmajati (2001) yang mendefinisikan bahwa paket wisata merupakan suatu rencana atau perjalanan wisata yang telah tersusun secara tetap, dengan harga tertentu yang telah termasuk pula biaya untuk transfer/pengangkutan, fasilitas akomodasi, serta darmawisata, objekobjek wisata, dan atraksi-atraksi yang telah tercantum di dalam acara tersebut.

\section{METODE PENELITIAN}

Penelitian ini mengambil lokasi di Desa Wisata Kerta, Kecamatan Payangan, Kabupaten Gianyar, Bali. Lokasi penelitian ini ditetapkan dengan fungsi utama sebagai daerah konvensi air, pengembangan agrowisata, dan culture heritage, yang dituangkan ke dalam Peraturan Daerah Kabupaten Gianyar Nomor 16 Tahun 2012 tentang RTRW, khususnya pada bagian kedua pasal 10 ayat 7

Data kualitatif dalam penelitian ini meliputi data mengenai gambaran umum Desa Wisata Kerta, identifikasi potensi wisata heritage, dan strategi pengemasan wisata heritage. Sumber data primer dalam penelitian ini adalah data yang diperoleh dari fakta-fakta langsung di tempat penelitian diambil dan diolah sendiri dari Desa Wisata Kerta dengan metode wawancara observasi serta dokumentasi. Sumber data sekunder dalam penelitian ini adalah data yang diperoleh berasal dari berbagai buku yang digunakan sebagai landasan teori yang sifatnya menunjang penelitian ini, seperti studi kepustakaan berupa hasil penelitian terdahulu dan literature-literatur lainnya yang berkaitan dengan penelitian ini.

Teknik pengumpulan data dalam penelitian ini, antara lain: observasi, wawancara dan dokumentasi. Observasi dilakukan untuk mengamati potensi wisata heritage di Desa Wisata Kerta. Wawancara yang dilakukan dalam penelitian ini adalah indepth interview, dan pihak yang berkompeten.

Teknik analisis data yang digunakan dalam penelitian ini adalah analisis deskriptif kualitatif. Analisis deskriptif kualitatif adalah upaya yang dilakukan dengan jalan bekerja dengan data, mengorganisasikan data, memilah-milahnya menjadi satuan yang dapat dikelola, mensintesiskannya, mencari dan menemukan pola, menemukan apa yang penting, apa yang dipelajari, dan memutuskan apa yang diceritakan kepada orang lain (Moleong, 2012). Dalam penelitian ini, aktivitas menganalisis data dilakukan dengan analisis data, Penyajian data, Dan penarikan kesimpulan 


\section{Hasil dan Pembahasan}

\section{a. Potensi Wisata Heritage di Desa Wisata Kerta.}

Desa Wisata Kerta adalah salah satu desa di Pulau Bali yang terletak di Kecamatan Payangan, Kabupaten Gianyar. Jarak Desa Wisata Kerta tidak terlalu jauh dari pusat kota Denpasar yaitu sekitar $63 \mathrm{~km}$, akses menuju Desa Wisata Kerta juga sangat mudah dijangkau, baik dengan kendaraan roda dua maupun roda empat dan membutuhkan waktu sekitar 90menit dari pusat kota Denpasar menuju Desa Wisata Kerta.

Desa Wisata Kerta mempunyai potensipotensi pariwisata yang sedang gencar untuk dikembangkan dengan didukung oleh potensi alam, potesi budaya, dan potensi sejarah yang dimiliki Desa Wisata Kerta, hal ini bisa menjadi modal dalam mengembangkan pariwisata Desa Kerta. Potensi-potensi pariwisata yang ada di Desa Kerta diantaranya adalah Sekar Bumi Farm, Jalur Trekking, Akar Raksasa Munduk Asri, Kebun Raya Gianyar, dan potensi wisata heritage seperti sarkofagus, tarian joget pingit, Pura Alas Angker, tarian gelagar, situs goa, Pura Bukit Mentik, hutan keramat, dan tradisi Bali Aga.

Di Desa Wisata Kerta potensi wisata agro (agrowisata) merupakan potensi yang paling dominan, akan tetapi Desa Wisata Kerta juga mempunyai potensi wisata heritage yang besar, hal tersebut dapat dilihat dari Desa Kerta yang memiliki sejarah yang yang sangat menarik untuk dibahas seperti adanya kisah legenda seorang Maha Rsi yang bernama Rsi Markandiya yang menjadikan Desa ini sebagai salah satu tempat persinggahannya. Selain memiliki kisah yang bersejarah, Desa Wisata Kerta juga mempunyai beberapa situs dan peninggalan bersejarah.

Desa Kerta mempunyai potensi budaya masa lalu dan potensi budaya yang masih hidup atau berlanjut (cultural heritage \& living cultural) hingga saat ini potensi budaya yang sudah ada dan akan dikembangkan menjadi produk/daya tarik wisata Desa Kerta, yaitu sarkofagus, situs goa, Pura Alas Angker, Pura Bukit Mentik, dan Hutan Keramat.

Pada zaman dahulu sarkofagus adalah tempat yang terbuat dari batu yang digunakan untuk menyimpan jenazah. Sarkofagus yang terdapat di Desa Kerta berada di area Pura
Kawitan Desa Pekraman Margatengah. Situs sarkofagus ini dibongkar pada tahun 1975, dan ditemukan perhiasan-perhiasan dan kerangka tulang manusia dalam sarkofagus tersebut.

Desa Kerta memiliki situs goa yang menyimpan cerita unik, goa tersebut diberi nama Goa Raksasa dan Goa Gerombolan. Goa Raksasa terletak di Banjar Pilan, Goa ini menyimpan cerita yang bernuansa mistis yang sangat menarik untuk diceritakan kepada wisatawan, dan diperkirakan Goa Raksasa dan Goa Gerombolan sudah ada sejak zaman prasejarah.

Pura Alas Angker merupakan salah satu pura terbesar di Desa Wisata Kerta dan memiliki nilai sejarah yang tinggi yang berpotensi untuk menarik wisatawan untuk mengunjungi pura ini. Pura Alas Angker memiliki pintu masuk yang cukup besar dan megah, terdapat beberapa pohon beringin berukuran besar yang mengelilingi pura ini, selain pohon beringin terdapat beberapa jenis pohon lainnya seperti pohon kayu putih dan pohon-pohon untuk keperluan peribadatan.

Selain Pura Alas Angker, di Desa Wisata Kerta tepatnya di Banjar Buntah terdapat Pura Bukit Mentik yang memiliki kisah yang menarik dan berpotensi untuk dijual kepada wisatawan, Pura Bukit Mentik ini berada di tengah persawahan sehingga akses menuju Pura Bukit Mentik ini akan disuguhkan dengan pemandangan persawahan yang indah. Akses menuju pura ini juga sudah terbilang baik karena sudah bisa dilalui baik oleh kendaraan roda dua maupun roda empat.Pura ini digunakan untuk bersembahyang oleh umat Hindu di Banjar Buntah. Masyarakat juga melaksanakan upacara-upacara tertentu di pura ini seperti piodalan yang dilaksanakan setiap enam bulan sekali.

Di Desa Wisata Kerta terdapat hutan milik masyarakat (hutan rakyat) maupun hutan milik banjar adat (hutan adat). Hutan rakyat adalah hutan yang ditanam secara sengaja untuk keperluan bahan baku bangunan, kerajinan maupun keperluan komersil. Sedangkan hutan adat adalah hutan milik adat, yang telah ada sejak dahulu.Hutan adat identik dengan keramat, sehingga keberadaannya sangat dijaga dan dilestarikan oleh masyarakat adat. Di tempat ini terdapat hutan adat yang cukup luas, tersebar di 
delapan desa adat/pekraman. Masyarakat setempat sangat percaya terhadap nilai keramat dari hutan ini.Bahkan masyarakat pun tidak berani untuk memetik tanaman, memotong kayu sembarangan, atau mengambil sesuatu dari dalam hutan tersebut. Karena masyarakat percaya jika mereka melakukan hal-hal tersebut mereka akan tertimpa hal yang di luar akal sehat manusia. Oleh sebab itu, wisatawan yang datang mengunjungi hutan keramat ini harus dihimbau agar tidak melanggar aturan-aturan yang telah ditetapkan oleh desa adat sekitar ketika akan memasuki hutan.

\section{b. Strategi Pengemasan Wisata Heritage di Desa Wisata Kerta}

Strategi pengemasan ialah pilihan tentang cara terbaik untuk mengkemas produk-produk wisata yang akan dijual kepada industri perjalanan wisata serta sebuah identitas untuk membedakannya dari produk-produk lainnya. Dan definisi yang sederhana untuk heritage adalah apa yang atau mungkin diwariskan, dapat mencakup tradisi, nilai, event historis, mesin industri dari masa lalu, rumah historis, koleksi seni, kegiatan kultural, dan kekayaan alam seperti pantai, pegunungan, flora dan fauna (Drummond, 2001).

Penelitian ini membahas mengenai pilihan cara terbaik untuk mengemas potensi wisata heritage di Desa Wisata Kerta yang akan dibuat menjadi sebuah produk pariwisata yang akan dijual kepada industri perjalanan wisata, serta membuat identitas atau branding untuk produk wisata heritage ini yang dapat membedakan dari produk pariwisata lainnya. Beberapa potensi yang dapat dikembangkan menjadi produk wisata heritage di Desa Kerta, diantaranya adalah (1) Hutan Keramat, (2) Situs Sarkofagus, (3) Situs Goa, (4) Pura Alas Angker, (5) Pura Bukit Mentik, (6) Tari Joget Pingit, (7) Tari Glagar, dan (8) Tradisi Bali Aga. Dimana potensipotensi tersebut mempunyai nilai sejarah dan cerita yang unik dan menarik dan berpotensi untuk dikembangkan sehingga akan sangat bermanfaat bagi masyarakat lokal, wisatawan, dan pengelola pariwisata di Desa Kerta. The National Trust mengungkapkan manfaat pengembangan wisata heritage yang sukses, mencakup :

1. Menarik investasi baru

2. Menciptakan lapangan pekerjaan baru

3. Revitalisasi pusat perkotaan dan lingkungan

4. Membangun kebanggaan masyarakat dan berwarganegara

5. Mendidik anak-anak tentang pusaka yang mereka miliki

Sehingga diharapkan dengan berkembangnya wisata heritage di Desa Wisata Kerta dapat menarik investasi baru untuk pengembangan pariwisata di Desa Kerta terutama wisata heritage-nya, dapat menciptakan lapangan pekerjaan baru untuk masyarakat lokal di Desa Wisata Kerta, dan merevitalisasi lingkungan Desa Wisata Kerta, kemudian bisa membangun rasa bangga masyarakat bahwa di Desa nya terdapat halhal yang bernilai sejarah tinggi, serta mendidik generasi penerus mengenai pusaka (heritage) yang mereka miliki.

Berdasarkan hasil wawancara dengan pengelola Desa Wisata Kerta, sebenarnya desa Kerta sudah ada rancangan untuk mengemas potensi wisata heritage yang mereka miliki, akan tetapi belum dijalankan dengan alasan bahwa potensi wisata heritage di Desa Wisata Kerta masih pada tahap explore dan penggalian data yang lebih mendalam.

Desa Wisata Kerta sudah melakukan pengembangan dan menjalankan berbagai aktivitas pariwisata, salah satu diantaranya adalah cycling. Desa Kerta sangat cocok dikembangkan aktivitas cycling karena memiliki wilayah yang cukup luas, dengan topografi landai dan berbukit-bukit. Potensi alam yang besar didukung dengan aksesibilitas yang memadai membuat Desa Kerta cocok untuk mengembangkan aktivitas wisata cycling yang dapat menambah wawasan dan pengalaman wisatawan tentang lingkungan alam, pertanian, budaya, dan aktivitas masyakat lokal. Sehingga menurut peneliti pemilihan strategi atau cara terbaik untuk mengkemas wisata heritage di Desa Wisata Kerta adalah menggabungkan dengan aktivitas cycling yang telah berkembang di Desa Wisata Kerta. Kegiatan cycling ini nantinya akan melewati delapan banjar yang ada di Desa Wisata Kerta. Selain potensi wisata heritage, 
disetiap banjar terdapat potensi-potensi pariwisata lainnya yang akan dilewati oleh wisatawan seperti area persawahan, area perkebunan, air terjun, subak, dan disepanjang jalur cycling wisatawan akan menikmati pemandangan yang indah dan suasana pedesaan yang asri dengan cuaca yang sejuk.

Pengemasan wisata heritage di Desa Wisata Kerta melihat dari beberapa aspek mulai dari branding, jalur cycling, peraturan, busana, makanan dan minuman, souvenir, dan perlengkapan. Berikut adalah penjelasan dari masing-masing aspek yang termasuk dalam pengemasan wisata heritage di Desa Wisata Kerta :

\section{1) Branding \& Tag Line}

Branding yang cocok digunakan untuk wisata heritage ini adalah "Kerta Heritage Tour", hal tersebut dikarenakan paket wisata ini akan menyusuri potensi budaya dan peninggalan bersejarah yang ada di Desa Wisata Kerta. Tag Line yang tepat untuk mengemas wisata heritage di Desa Wisata Kerta adalah "Kerta Heritage Tour: Reminds Who You Are". Branding ini mempunyai tujuan untuk memberitahukan bahwa wisatawan tidak hanya mengetahui atau belajar mengenai sejarah-sejarah dari situs heritage tetapi juga mengingatkan wisatawan agar sadar dan peduli terhadap warisan budaya yang mereka miliki dan bagaimana pentingnya warisan budaya itu sehingga harus dijaga dan dilestarikan karena warisan budaya (heritage) merupakan bagian dari identitas diri sendiri.

2) Jalur Cycling

Cycling di Desa Wisata Kerta mengambil start dari Bumi Perkemahan Pucak Sari dan di akhiri di tempat yang sama dengan arah memutar/ mengelilingi Desa Wisata Kerta. Jalur cyclingini akan menempuh lama perjalanan sekitar 240 menit. Berikut adalah tempat-tempat yang akan dilalui dan disinggahi :

Cycling Start Point dan Finish Point di Bumi Perkemahan Puncak Sari, Bumi Perkemahan Puncak Sari merupakan tempat berkumpul peserta cycling. Dari sini wisatawan akan berkumpul dan memilih sepeda yang sudah disediakan pihak pengelola Desa Wisata Kerta. Disini juga wisatawan akan dijelaskan mengenai peraturan selama cycling maupun peraturan yang berlaku di situs-situs heritage Desa Wisata Kerta. Setelah kegiatan cycling ini selesai wiatawan akan kembali ke Bumi Perkemahan Pucak Sari.

\section{a. Pemberhentian Pertama : Goa Raksasa}

Pemberhentian pertama dari kegiatan cycling ini yaitu Goa Raksasa, Goa ini merupakan goa yang menyimpan cerita bernuansa mistis dan terletak di Banjar Pilan. Wisatawan harus lebih berhati-hati untuk mencapai situs goa ini karena akses jalan masuk menuju situs goa ini cukup terjal untuk dilalui. Wisatawan bisa menikmati situs ini dengan melihat-lihat keadaan di sekitar goa dan berfoto-foto dengan latar belakang mulut goa ini serta mendengarkan pemaparan guide mengenai sejarah dan cerita Goa Raksasa.

\section{b. PemberhentianKedua: Goa Gerombolan}

Pemberhentian kedua dari kegiatan cycling ini adalah Goa Gerombolan. Goa ini berbentuk ruangan besar dan tidak bisa terlihat jelas dari luar karena mulut goa berada tepat di balik air terjun kecil, Goa Gerombolan pada zaman dahulu digunakan untuk tempat persembunyian para gerombolan yang sering merampas harta warga yang ada di wilayah ini, untuk mencapai situs goa ini, wisatawan harus lebih berhatihati karena akses jalan masuk menuju situs goa ini cukup terjal untuk dilalui. Wisatawan bisa menikmati situs ini dengan masuk ke dalam goa dan melihat-lihat keadaan di dalam goa serta berfoto-foto dengan latar belakang goa ini sambil mendengarkan pemaparan guide mengenai sejarah dan cerita Goa Gerombolan.

\section{c. Pemberhentian Ketiga : Hutan Keramat di Banjar Pilan}

Pemberhentian ketiga dari kegiatan cycling ini adalah Hutan Keramat di Banjar Pilan. Hutan ini disebut hutan keramat karena terkenal angker dan banyak kisah mistis yang terjadi.Di dalam hutan ini terdapat berbagai jenis flora dan fauna hidup. Wisatawan bisa menikmati hutan keramat ini dengan sekadar berfoto-foto dengan latar belakang hutan dan mendengarkan pemaparan guide mengenai bagaimana hutan ini bisa disebut sebagai hutan keramat. Namun, perlu diingat bahwa adanya peraturan adat yang perlu dihimbau kepada wisatawan yaitu dilarang memetik tanaman jenis apapun yang terdapat di Hutan Keramat ini. Setelah pemberhentian di hutan 
keramat, wisatawan akan kembali melanjutkan perjalanannya dan melewati Banjar Seming dan Banjar Saren. Selama perjalanan melewati Banjar Seming, wisatawan akan disuguhkan dengan pemandangan alam dan area persawahan yang asri. Kemudian selama perjalanan wisatawan melewati Banjar Saren, wisatawan akan disuguhkan dengan pemandangan subak. Setelah melewati kedua banjar tersebut, wisatawan akan melakukan pemberhentian selanjutnya.

\section{d. Pemberhentian Keempat: Pura Bukit Mentik di Banjar Buntah}

Pemberhentian keempat dari kegiatan cycling ini adalah Pura Bukit Mentik di banjar Buntah.Pura Bukit Mentik ini berada di tengah persawahan sehingga selama melewati akses menuju Pura Bukit Mentik ini wisatawanakan disuguhkan dengan pemandangan persawahan yang indah. Untuk askes menuju Pura ini juga sudah terbilang baik karena sudah bisa dilalui baik oleh kendaraan roda dua maupun roda empat.Bagi wisatawan yang beragama Hindu, ketika memasuki kawasan pura dipersilakan untuk sembahyang, sedangkan bagi wisatawan nonHindu dipersilakan untuk memasuki pura sekadar untuk berfoto-foto di area pura sambil mendengarkan pemaparan guide mengenai sejarah Pura Bukit Mentik. Namun, perlu dihimbau kepada seluruh wisatawan yang mengunjungi pura ini bahwa, terdapat beberapa peraturan yang perlu ditaati oleh setiap pengunjung pura, diantaranya memakai pakaian adat, minimal menggunakan selendang dan adanya larangan seperti pada umumnya, bahwa perempuan yang sedang menstruasi dilarang memasuki pura.

\section{g. Pemberhentian Kelima : Banjar Penyabangan}

Pemberhentian kelima dari kegiatan cycling ini adalah Banjar Penyabangan untuk menyaksikan Tarian Joget Pingit.Tarian ini sebenarnya ditarikan selamat 40 menit, namun untuk mempersingkat waktu tarian ini disuguhkan kepada wisatawan hanya 5 sampai 10 menit saja. Sebelum menyaksikan pementasan Tari Joget Pingit, guideakan menjelaskan terlebih dahulu sejarah mengenai tarian ini. Selanjutnya, wisatawan akan melanjutkan kembali perjalanannya melalui Banjar Mawang. Selama melewati Banjar
Mawang, wisatawan akan disuguhkan dengan pemandangan subak dan pemandangan air terjun.

\section{e. Pemberhentian keenam : Pura Alas Angker di Banjar Kerta}

Pemberhentian keenam dari kegiatan cycling ini adalah Pura Alas Angker di Banjar Kerta.Pura Alas Angker ini merupakan pura terbesar di Desa Wisata Kerta.Akses menuju pura ini terbilang mudah karena sudah dapat dilalui oleh kendaraan roda empat maupun roda dua dengan jalan yang sudah dibeton. Bagi wisatawan yang beragama Hindu dipersilakan untuk sembahyang jika ingin, kemudian wisatawan juga dipersilakan jika ingin berfoto-foto dengan latar belakang pura sambil mendengarkan pemaparan guide mengenai sejarah Pura Alas Angker. Ketika akan memasuki pura ini, wisatawan dihimbau untuk mentaati peraturan yang sudah ditetapkan, yakni menggunakan pakaian yang sopan dan menggunakan selendang serta bagi perempuan yang sedang menstruasi dilarang memasuki pura.

\section{f. Pemberhentian Ketujuh : Banjar Margatengah}

Pemberhentian ketujuh dari kegiatan cycling ini adalah Banjar Margatengah untuk menyaksikan Tari Gelagar.Di pemberhentian ini, wisatawan dipersilakan untuk menyaksikan pementasan Tari Gelagar. Namun, sebelum menyaksikan tarian ini, wisatawan akan mendengarkan pemaparan dari guide mengenai sejarah Tari Gelagar terlebih dahulu.

\section{h. Pemberhentian Kedelapan : Tradisi Bali Aga di Banjar Margatengah}

Pemberhentian kedelapan dari kegiatan cycling ini adalah Banjar Margatengah untuk mengunjungi Suku Bali Aga yang ada di sana. Di pemberhentian ini, wisatawan akandijelaskan oleh guide mengenai tradisi Bali Aga

\section{i. Pemberhentian Kesembilan \\ Sarkofagus di Banjar Margatengah}

Pemberhentian kesembilan dari kegiatan cycling ini adalah Sarkofagus di Banjar Margatengah. Wisatawan harus lebih berhatihati dalam mengendarai sepedanya, karena akses jalan masuk menuju situs sarkofagus ini masih belum diaspal dan masih berupa jalanan tanah dan berbatu. Wisatawan bisa menikmati 
situs ini dengan sekadar berfoto-foto di area situs sarkofagus dan mendengarkan pemaparan guide mengenaisejarah situs ini.Perlu dihimbau bagi wisatawan yang akan mengunjungi situs ini terdapat larangan yang perlu ditaati, yaitu bagi perempuan yang sedang mestruasi dilarang untuk memasuki area situs sarkofagus.Setelah mengunjungi area situs sarkofagus, wisatawan akan melanjutkan kembali perjalanannya menuju finish point di Banjar Pilan dan kembali ke start point di bumi perkemahan. Di sana wisatawan akan beristirahat dan mendapatkan kudapan yang disediakan panitia. Dengan kembalinya wisatawan ke bumi perkemahan, maka kegiatan cycling ini selesai.

3) Peraturan

Peraturan dari wisata heritage ini mengacu pada peraturan yang terdapat dalam awig-awig (peraturan desa), dikarenakan wisata heritage yang dikombinasikan dengan cycling ini bukan seperti cyclingpada umumnya jadi peraturannya juga berbeda. Tempat yang dilalui dan disinggahi juga masih memiliki kesucian serta kesakralan, oleh karena itu peraturan yang paling mendasar adalah peraturan yang pada umumnya terdapat di kawasan-kawasan suci.Seperti yang sudah dijelaskan di atas, bahwa perempuan yang sedang menstruasi dilarang atau tidak diperbolehkan mengikuti wisataini dan wisatawan harus bisa menjaga tutur kata dan perilakunya.

4) Busana

Terkait dengan busana atau pakaian yang dikenakan, wisatawan harus menggunakan pakaian setidaknya kaos dengan celana yang panjangnya melebihi lutut. Karena wisata ini juga mengunjugi kawasan suci, maka wisatawan diwajibkan membawa selendang yang dimasukkan ke dalam tas, dan digunakan pada saat tiba di kawasan suci. Bagi wisatawan yang mengenakan celana dengan panjang diatas lutut maka akan diberikan kamen (kain sarung).

5) Makanan dan Minuman

Wisata heritage Desa Wisata Kerta ini di dalamnya juga menyuguhkan wisatawan makanan dan minuman tradisional khas Bali, seperti makanan ringan atau camilan berupa kue seperti jaje laklak, jaje uli, jaje begina dan masih banyak jajanan tradisional
lainnya.Untuk minumannya sendiri wisatawan bisa menikmati air mineral, kopi, atau teh.

6) Souvenir

Souvenir yang didapatkan ketika telah melakukan wisata heritage ini berupa miniatur atau patung kecil seperti ukuran pion catur dengan ukiran yang menyerupai situs-situs heritage di Desa Wisata Kerta.

\section{PENUTUP}

\section{a. Kesimpulan}

Strategi pengemasan wisata hertage yang dilakukan oleh peneliti adalah dengan mengkombinasikan wisata heritage dengan aktivitas wisata cycling dengan tujuan untuk pengembangan wisata heritage yang sukses, yang dapat member manfaat, seperti menarik investasi baru, menciptakan lapangan pekerjaan baru untuk masyarakat lokal, merevitalisasi lingkungan Desa Wisata Kerta, bisa membangun rasa kebanggaan masyarakat bahwa di desanya terdapat hal-hal yang bernilai sejarah tinggi serta mendidik generasi penerus mengenai pusaka (heritage) yang mereka miliki.

Pengemasan wisata heritage di Desa Wisata Kerta mempunyai branding "Kerta Heritage Tour" dan tag line "Kerta Heritage Tour: Reminds Who You Are". Wisata heritage yang dikombinasikan dengan wisata cycling ini akan mengelilingi Desa Wisata Kerta dan melewati delapan banjar yang ada di sana dengan start point dan finish point di Bumi Perkemahan Puncak Sari, Banjar Pilan.

\section{b. Saran}

Adapun saran yang dapat diberikan, sebagai berikut:

1. Terwujudnya wisata heritage di Desa Wisata Kerta, pemerintah akan dapat merasakan pemasukan/income yang telah didapatkan dari wisata minat khusus ini sehingga akan lebih baik jika pemerintah membuat dan mengadakan pelatihan bahasa asing untuk masyarakat lokal sehingga masyarakat dapat turut serta menjadi guide lokal untuk aktivitas wisata Kerta Heritage Tour.

2. Terwujudnya wisata heritage di Desa Wisata Kerta, masyarakat lokal dapat berperan serta di dalam kegiatan ini. Dari kegiatan ini masyarakat lokal dapat merasakan manfaat serta kegunaan dari 
wisata heritage itu sendiri, selain itu masyakat lokal juga akan mendapat pendapatan atau penghasilan. Penghasilan tersebut dapat dihasilkan dari penjualan makanan dan minuman, menjual souvenir yang dibutuhkan untuk wisata heritage, dapat menjadi guide lokal untuk aktivitas wisata Kerta Heritage Tour, sehingga tujuan wisata heritage disini adalah untuk lebih mensejahterakan masyarakat lokal dan mengenalkan potensi wisata heritage yang terdapat di Desa Wisata Kerta.

3. Bagi akademisi yang ingin melakukan penelitian disarankan untuk menggali informasi lebih mendalam mengenai perencanaan pariwisata di Desa Wisata Kerta dengan melakukan wawancara mendalam kepada pihak-pihak yang berkompeten di Desa Wisata Kerta.

\section{DAFTAR PUSTAKA}

Bungin, Burhan. 2003. Analisis Data Penelitian Kualitatif. Jakarta: PT.Grafindo

Bungin, Burhan. 2003. Penelitian Kualitatif Edisi Kedua. Jakarta: PT.Prenada Media Group

Darmajati, R. S. 2001. Istilah-Istilah Dunia Pariwisata. Jakarta: PT.Pradnya Paramitha

Gunawan, I. M. 2016. Pengembangan Agrowisata untuk Kemandirian Ekonomi dan Pelestarian Budaya di Desa Kerta Payangan, Gianyar. Jurnal Master Pariwisata (JUMPA)

Gunawan, I. M. 2016. Pengembangan Agrowisata Desa Kerta sebagai Pariwisata Berkelanjutan di Kawasan Agropolitan Payangan Kabupaten Gianyar. Tesis. Denpasar: Universitas Udayana 